\title{
POTENSI EKSTRAK METANOL DAUN MANGGA BACANG (Mangiferafoetida L.) SEBAGAI ANTIBAKTERI TERHADAP Enterobacter aerogenes DAN IDENTIFIKASI GOLONGAN SENYAWA AKTIFNYA
}

\author{
Ely Setiawan*, Tien Setyaningtyas, Dwi Kartika, Dian Riana Ningsih \\ Jurusan Kimia FMIPA \\ Universitas Jenderal Soedirman \\ *email: elsant_13@yahoo.com
}

Received 16 Oktober 2017

Accepted 28 Nopember 2017

\begin{abstract}
Abstrak
Enterobacter aerogenes merupakan bakteri penyebab berbagai macam infeksi. Salah satu pengobatan berbagai penyakit infeksi yaitu dengan pemberian antibiotik. Penggunaan antibiotik sintetik secara terus menerus dapat menyebabkan resistensi, sehingga untuk mengatasinya diperlukan pencarian bahan obat alami. Ekstrak tanaman yang berpotensi sebagai antibakteri, salah satunya yaitu ekstrak daun mangga bacang (Mangifera foetidaL.). Penelitian ini bertujuan untuk mengetahui potensi ekstrak daun mangga bacang sebagai antibakteri terhadap E. aerogenes, penentuan konsentrasi hambat tumbuh minimum (KHTM) dan mengidentifikasi golongan senyawa aktif dari ekstrak daun mangga bacang. Daun mangga bacang di ekstraksi secara maserasi menggunakan pelarut metanol. Ekstrak yang diperoleh diuji aktivitas antibakteri dengan menggunakan metode difusi sumur. Penentuan konsentrasi hambat tumbuh minimum ekstrak mangga bacang menggunakan konsentrasi 1000 ppm, 500 ppm, 250 ppm, 125 ppm, 65 ppm, 30 ppm, 15 ppm, 10 ppm, 5 ppm. Ekstraksi daun mangga bacang menunjukan rendemen sebesar 10,61\% (b/b) dan diameter zona hambat aktivitas antibakteri konsentrasi $1000 \mathrm{ppm}$ sebesar5,46 mm. KHTM ekstrak metanol daun mangga bacang terhadap E. aerogenes yaitu pada konsentrasi 5 ppm dengan diameter zona hambat sebesar $1,78 \mathrm{~mm}$. Berdasarkan hasil uji fitokimia ekstrak metanol daun mangga bacang menunjukkan adanya senyawa golongan alkaloid, flavonoid, stereoid, polifenol, tanin, dan saponin.
\end{abstract}

Katakunci: antibakteri, Enterobacter aerogenes, Mangifera foetida L., metanol

\begin{abstract}
Enterobacter aerogenesis causes various bacterium infections. One of the treatment of various infectious diseases is by antibiotics treatment. The long-term use of synthetic antibiotics causes antibiotic resistance, so that research exploration of new antibiotic is needed. Plant extracts potentially as an antibacterial, one of the misleaves extract of mango bacang (Mangifera foetida L.). This study aimed to examine the potential of leaves mango bacang extract as an antibacterial againts E.aerogenes, the minimum inhibition concentration (MIC) and active compounds of leaves mango bacang extract. Mango leaves were extracted by maceration using methanol. The extract obtained was tested anti bacterial activity using the diffusi on wells method. The determination of MIC was used various concentrations of 1000 ppm, 500 ppm, 250 ppm, 125 ppm, 65 ppm, 30 ppm, 15 ppm, 10 $\mathrm{ppm}$, and $5 \mathrm{ppm}$. The extraction mango bacang leaves with yielded $10.61 \%(\mathrm{~b} / \mathrm{b})$ and diameter of zone of the antibacterial activity extract of $1000 \mathrm{ppm}$ was $5.46 \mathrm{~mm}$. The MIC
\end{abstract}


of the methanol extract against E.aerogenes was $5 \mathrm{ppm}$ with the zone diameter of $1.78 \mathrm{~mm}$. Phytochemistry analysis of mango bacang leaves extract using methanol result the alkaloid, flavonoid, stereoid, catakin, tannin, and saponin.

Keywords: antibacterial, Enterobacter aerogenes, Mangifera foetida L., methanol

\section{Pendahuluan}

Infeksi bakteri merupakan invasi dan multiplikasi mikroorganisme dalam jaringan tubuh yang menghasilkan tanda dan gejala seperti respon imun. Berbagai jenis penyakit infeksi disebabkan oleh adanya bakteri patogen seperti, Enterobacter aerogenes, Staphylococcus aureus, Eschericiacoli dan Vibrio cholera (Irawati, 2011). E. aerogenes merupakan bakteri nosokomial dan patogen yang dapat menyebabkan infeksi opurtunistik diantaranya infeksi saluran pernafasan bawah, infeksi kulit, saluran kemih dan sepsis. Dewasa ini, infeksi oportunistik menyebabkan 1,4 juta kematian setiap hari di seluruh dunia (UNAIDS, 2007).

Salah satu penyembuhan atau pengobatan berbagai penyakit infeksi yaitu dengan pemberian antibiotik sintetik. Namun penggunaan antibiotik sintetik memiliki beberapa kekurangan, diantaranya kecenderungan menimbulkan hipersensitivitas secara lokal pada kulit seperti reaksi alergi dan reaksi toksik. Selain itu penggunaan antibiotik sintetik secara terus menerus dapat menyebabkan resistensi (Ganiswara, 2003).Mengatasi masalah tersebut, diperlukan penelitian guna mencari alternatif baru yang bersifat alami yaitu dengan mengisolasi senyawa aktif dari tumbuhan yang berkhasiat obat untuk selanjutnya dapat dijadikan sebagai antibiotik alami.

Antibiotik alami pada saat ini banyak digunakan karena menurut beberapa penelitian memiliki efek samping yang ringan karena masih bisa dicerna oleh tubuh. Salah satu tumbuhan yang berpotensi sebagai obat alami yaitu tanaman mangga bacang (Mangifera feotida $\mathrm{L}$ ). Bagian dari tumbuhan mangga yang dapat dimanfaatkan untuk obat alami salah satunya yaitu daunnya. Daun mangga bacang mudah diperoleh dan jumlahnya melimpah akan tetapi belum banyak dimanfaatkan meskipun memiliki potensi yang besar. Potensi ekstrak daun mangga (M. indica L.) yaitu sebagai senyawa antimikrobia yang dapat menghambat pertumbuhan bakteri diantaranya E. Coli, $S$. aureus, Klebsiella pneumonia, Salmonella typhi, Listeria monocytogeneses, Campylobacter jejuni, Candidasp, Zygosaccharomyces sp., Fusarium sp., Aspergillus sp., Rhizopus sp. dan Penicillium sp. (Masibo and $\mathrm{He}$, 2009).

Berdasarkan uraian tersebut, maka akan dilakukan penelitian tentang potensi daun mangga bacang (M. Foetida L.) sebagai antibakeri terhadap $E$. aerogenes dan mencari senyawa aktif yang berpotensi sebagai antibakteri. Penentuan Konsentrasi Hambat Tumbuh Minimum (KHTM) terhadap E. aerogenes untuk mengetahui konsentrasi minimal suatu senyawa antibakteri yang dapat menghambat pertumbuhan mikroorganisme. Aktivitas antibakteri menggunakan metode difusi dan aktivitas antibakteri ekstrak daun mangga bacang (Mangifera foetidaL) ditandai adanya zona bening disekitar lubang.

\section{Metode Penelitian}

\section{Bahan dan Alat}

Bahan yang digunakan dalam penelitian ini adalah daun mangga bacang (Mangifera foetida L.) yang diambil dari kelurahan Sumampir Purwokerto, akuades, isolat bakteri Enterobacter aerogenes dari laboratorium Mikrobiologi Fakultas Biologi Unsoed, media Nutrient Agar (NA), media Nutrient Broth (NB), media Pepton Yeast Glucose Agar 
(PYGA), akuades steril, tetrasiklin, kertas saring, $\mathrm{I}_{2}, \mathrm{KOH}, \mathrm{HCl}, \mathrm{Hcl}$ pekat, serbuk $\mathrm{Mg}$, pereaksi Mayer, pereaksi $\mathrm{FeCl}_{3}$, pereaksi Liberman-Burchard, dan tisue. Alat yang digunakan dalam penelitian ini adalah blender, oven, autoklaf, timbangan analitik, alat rotary evaporator (Buchii, Indonesia), waterbath, filler, pipetukur, hotplate, mikropipet, lampu spiritus, jarumose, Drugalsky, cawan Petri, lampu UV Cabinet II $366 \mathrm{~nm}$, alat spektrofotometer UV-Vis (Shimadzu UV1601 SA, Japan).

\section{Prosedur Penelitian}

Ekstraksi (Ningsih, dkk., 2014)

Sebanyak kurang lebih 100 gram serbuk daun mangga diekstraksi secara maserasi dengan menggunakan $350 \mathrm{~mL}$ metanol sampai semua serbuk terendam dan diaduk lalu ditutup dan disimpan selama tiga hari. Pengadukan dilakukan kurang lebih sebanyak tiga kali sehari. Selanjutnya dilakukan penyaringan sehingga didapat filtrat dan residu. Residu yang dihasilkan kemudian dimaserasi kembali dengan penambahan $50 \mathrm{~mL}$ metanol selama 3 hari dan dilakukan penyaringan setiap hari. Semua filtrat yang dihasilkan disatukan menjadi satu dalam satu wadah sebagai filtrat ekstrak metanol. Kemudian filtrat tersebut dipekatkan dengan vacuum rotary evaporator hingga didapatkan ekstrak yang kental kemudian ditimbang.

\section{Regenerasi bakteri uji}

Bakteri yang akan dipakai untuk uji antibakteri harus diregenerasikan terlebih dahulu sebelum digunakan. Bakteri stok yang merupakan kultur primer, mula-mula dibiakkan ke dalam media NA miring, yaitu sebanyak satu ose bakteri digoreskan ke media NA miring lalu diinkubasi pada suhu $37{ }^{\circ} \mathrm{C}$ selama 24 jam. Biakan ini merupakan aktivitas awal stok bakteri yang kemudian disimpan pada suhu $5{ }^{\circ} \mathrm{C}$.
Uji aktivitas antibakteri dengan metode difusi

Uji awal aktivitas antibakteri dilakukan dengan cara difusi (Ningsih, dkk, 2014). Sebanyak satu ose bakteri dari stok biakan diambil lalu diinkubasi di dalam $10 \mathrm{~mL}$ media cair (Nutrient Broth) selama 18-24 jam pada suhu $37{ }^{\circ} \mathrm{C}$ dan sambil dikocok menggunakan penangas air bergoyang dengan kecepatan $100 \mathrm{rpm}$. Kemudian sebanyak $5 \mathrm{~mL}$ biakan bakteri diambil lalu diukur Odnya dengan nilai kurang dari satu pada panjang gelombang $620 \mathrm{~nm}$. Bila nilai $\mathrm{OD}>1$ diambil biakan sebanyak 50 $\mu \mathrm{L}$, bila $\mathrm{OD}<1$ biakan diambil $100 \mu \mathrm{L}$, lalu dituangkan $15 \mathrm{~mL}$ media Pepton Yeast Glucose Agar (PYGA) bersuhu $\pm 40{ }^{\circ} \mathrm{C}$ dan dibiarkan memadat kemudian biakan yang diambil disebarkan dalam cawan Petri. Setelah itu agar dilubangi dengan diameter $\pm 8 \mathrm{~mm}$ menggunakan crockbor. Ke dalam lubang tersebut dimasukkan ekstrak daun mangga sebanyak $50 \mu \mathrm{L}$ dengan konsentrasi yang digunakan untuk uji pendahuluan daya hambat adalah 1000 ppm lalu diinkubasi pada suhu $37{ }^{\circ} \mathrm{C}$ selama 24 jam.

Zona bening yang terlihat di sekeliling lubang, menandakan adanya aktivitas antibakteri pada sampel kemudian zona bening yang terbentuk diukur menggunakan jangka sorong. Setelah diketahui bahwa ekstrak daun mangga mempunyai aktivitas antibakteri, kemudian ekstrak daun mangga ditentukan Konsentrasi Hambat Tumbuh Minimum (KHTM) terhadap bakteri E. aerogenes dengan metode yang sama.

\section{Penentuan Konsentrasi Hambat Tumbuh Minimum (KHTM)}

Konsentrasi Hambat Tumbuh Minimum (KHTM) merupakan konsentrasi terendah yang masih memberikan efek penghambatan pertumbuhan pada mikroorganisme. Penentuan KHTM mempunyai tujuan untuk mengetahui kadar minimum bahan aktif yang diperlukan untuk menghambat pertumbuhan mikroorganisme. Penelitian 
ini menggunakan mikroorganisme berupa bakteri Enterobacter aerogenes. Penentuan ini dilakukan dengan konsentrasi ekstrak metanol daun mangga bacang yang diencerkan secara berseri, yaitu $1000,500,250,125,65,30,15,10$, 5 , dan $1 \mathrm{ppm}$. Metode penentuan dilakukan dengan cara difusi agar (sumuran). Biakkan bakteri diinokulasikan pada cawan petri dengan media NA kemudian diberi lubang dengan bantuan crock bor. Ekstrak berbagai konsentrasi dimasukkan dalam lubang pada media NA sebanyak 50 $\mu \mathrm{L}$, setelah itu diinkubasi selama $1 \times 24$ jam pada suhu $37^{\circ} \mathrm{C}$. Kontrol negatif yang digunakan adalah aquades sedangkan kontrol positif menggunakan larutan tetrasiklin 1000 ppm. KHTM ditentukan dengan mengukur zona hambat yang terdapat disekitar lubang pada masingmasing konsentrasi ekstrak dengan jangka sorong.

Identifikasi senyawa kimia ekstrak daun mangga(Harborne, 1987)

Uji senyawa alkaloid

Sebanyak $2 \mathrm{~mL}$ sampel dilarutkan dalam $2 \mathrm{~mL} \mathrm{HCl} \mathrm{2 \% ,} \mathrm{dipanaskan} 5$ menit dan disaring. Filtrat yang diperoleh ditetesi dengan pereaksi Mayer sebanyak 2-3 tetes. Adanya senyawa alkaloid ditujukkan dengan terbentuknya endapan putih.

\section{Uji senyawa flavonoid}

Sebanyak $2 \mathrm{~mL}$ sampel dilarutkan dalam $2 \mathrm{~mL}$ metanol, kemudian ditambahkan serbuk $\mathrm{Mg}$ dan $\mathrm{HCl}$ pekat sebanyak 5 tetes. Adanya senyawa flavanoid ditunjukkan dengan terbentuknya warna merah atau jingga.

\section{Uji senyawa saponin}

Sebanyak $2 \mathrm{~mL}$ sampel dilarutkan dalam aquades pada tabung reaksi ditambah 10 tetes $\mathrm{KOH}$ dan dipanaskan dalam penangas air $50{ }^{\circ} \mathrm{C}$ selama 5 menit, dikocok selama 15 menit. Jika terbentuk busa mantap setinggi $1 \mathrm{~cm}$ dan tetap stabil selama 15 menit menunjukkan adanya senyawa saponin.

\section{Uji senyawa stereoid dan terpenoid}

Sebanyak $2 \mathrm{~mL}$ sampel ditambah dengan pereaksi Liberman-Burchard 1 $\mathrm{mL}$. Adanya senyawa terpenoid ditujukkan dengan terbentuknya warna biru tua atau hijau kehitaman.

\section{Uji senyawa polifenol}

Sebanyak $2 \mathrm{~mL}$ sampel dilarutkan dalam aquades $10 \mathrm{~mL}$, dipanaskan 5 menit dan disaring. Filtrat yang terbentuk ditambahkan dtambahkan 4-5 tetes $\mathrm{FeCl}_{3}$ $5 \%(\mathrm{~b} / \mathrm{v})$. Adanya fenol ditujukkan dengan terbentuknya warna biru tua atau hijau kehitaman.

\section{Uji senyawa tanin}

Sebanyak $2 \mathrm{~mL}$ sampel ditambah dengan pereaksi $\mathrm{FeCl}_{3}$. Adanya senyawa tanin ditunjukkan dengan terbentuknya warna biru tua atau hijau kehitaman.

\section{Hasil dan Pembahasan \\ Preparasi Sampel}

Sampel daun mangga bacang yang telah dicuci bersih dikeringkan tanpa terkena sinar matahari langsung selama 17 hari sampai kering patah. Pengeringan bertujuan untuk mendapatkan sampel yang tidak mudah rusak, sehingga dapat disimpan dalam waktuyang lama. Pengeringan dapat mengurangi kadar air dalam sampel yang dapat menyebabkan terjadinya reaksi enzimatis yang mengakibatkan rusaknya sampel karena susunan senyawa yang terdapat dalam daun tersebut telah berubah. Sampel daun manga bacang yang telah kering patah dibuat serbuk dengan cara diblender agar ukuran partikelnya lebih kecil sehingga dapat memperluas kontak dan meningkatkan daya interaksi sampel dengan pelarut. Pembuatan sampel menjadi serbuk dapat merusak dinding sel yang menyebabkan pelarut lebih mudah menarik senyawa yang terkandung di dalam sel tersebut sehingga jumlah ekstrak yang diperoleh optimal. Serbuk daun mangga selanjutnya dilakukan ekstraksi secara maserasi. 


\section{Maserasi Sampel}

Sampel daun mangga bacang diekstrak menggunakan metode maserasi. Maserasi adalah proses penyaringan pelarut dengan beberapakali pengadukan pada temperatur ruang. Teknik ini mempunyai beberapa kelebihan antara lain alat yang dipakai sederhana, hanya dibutuhkan bejana perendaman tetapi menghasilkan produk yang baik, selain itu dengan teknik ini zatzat yang tidak tahan panas tidak akan rusak (Voigt, 1994). Sampel yang digunakan pada proses maserasi berupa serbuk bertujuan untuk memperluas permukaan sehingga interaksi pelarut dengan senyawa yang akan diambil lebih efektif dan senyawa dapat terekstrak secara sempurna. Proses perendaman menyebabkan cairan menembus dinding sel dan masuk ke dalam rongga sel yang mengandung metabolit sekunder, metabolit sekunder akan larut dan karena adanya perbedaan konsentrasi antara larutan di dalam dan di luar sel, maka larutan yang lebih pekat akan keluar sel membawa metabolit sekunder. Proses ini terus berulang sampai terjadi keseimbangan konsentrasi antara larutan di dalam dan di luar sel.

Maserasi sampel dilakukan dengan menggunakan pelarut metanol karena sifatnya yang mampu melarutkan hampir semua zat, baik yang bersifat polar, semi polar,dan nonpolar. Filtrat yang telah dihasilkan kemudian dipekatkan dengan rotary evaporator pada suhu $60{ }^{\circ} \mathrm{C}$ mendekati titik didih metanol $64,5{ }^{\circ} \mathrm{C}$ dengan laju perputaran $55 \mathrm{rpm}$. Prinsip rotary evaporator adalah proses pemisahan ekstrak dari cairan sampel dengan pemanasan yang dipercepat oleh putaran dari labu, sehingga cairan sampel dapat menguap 5-10 ${ }^{\circ} \mathrm{C}$ di bawah titik didih pelarutnya disebabkan oleh karena adanya penurunan tekanan. Hasil maserasi menghasilkan ekstrak metanol pekat yang berwarna hijau kehitaman sebanyak 10,61 gram dengan rendemen $10,61 \%$ (b/b). Ekstrak pekat metanol yang diperoleh disimpan dalam gelas piala yang dibungkus dengan alumunium foil, diletakan dalam lemari pendingin agar tahan lama dan terhindar dari cahaya, selanjutnya dilakukan uji aktivitas antibakteri. Hasil penelitian lain menyatakan maserasi ekstrak n-butanol daun mangga katsuri sebanyak $450 \mathrm{~g}$ menghasilkan ekstrak pekat n-butanol sebesar 1,69\% (Firdausi, 2015). Maserasi menggunakan metanol menghasilkan rendemen lebih besar dibandingkan nbutanol. Penggunaan pelarut metanol pada proses maserasi karena pelarut tersebut dapat melarutkan hampir semua senyawa metabolit sekunder yang bersifat nonpolar, semipolar, dan polar. Selain itu metanol mempunyai titik didih yang relatif rendah sehingga mudah diuapkan, sedangkan senyawa polar yang terekstrak dalam pelarut n-butanol hanya kelompok senyawa yang mempunyai titik didih mendekati titik didih n-butanol dan metabolit sekunder yang bersifat polar (Arifin, 2006).

\section{Uji Aktivitas Antibakteri}

Uji aktivitas antibakteri daun mangga bacang terhadap bakteri $E$. aerogenes dilakukan dengan metode difusi sumur. Metode difusi sumur digunakan karena hasil dari metode ini akan lebih menampakan hasil zona hambat yang nyata dan sampel dapat di absorbsi oleh media secara menyeluruh sehingga pertumbuhan bakteri merata pada media agar (Volk, 1990). Media yang digunakan untuk uji aktivitas antibakteri adalah medium PYGA (Pepton Yeast Glucose Agar). Medium ini mengandung glukosa dalam jumlah banyak yang dibutuhkan untuk pertumbuhan bakteri. Sebanyak50 $\mu \mathrm{L}$ inokulum E.aerogenes dalam medium NB (Nutrient Broth) disebar pada medium PYGA secara aseptis. Sampel daun mangga bacang sebanyak $50 \mu \mathrm{L}$ dimasukkan ke dalam medium PYGA yang telah dilubangi dengan crockbor dan diinkubasi selama $1 \times 24$ jam pada suhu $37^{\circ} \mathrm{C}$. Setelah proses inkubasi dilakukan pengukuran diameter zona hambat berupa zona bening disekitar 
sumur yang menunjukkan penghambatan pertumbuhan mikroba atau aktivitas antibakteri (Pelczar dan Chan, 1996).

Uji aktivitas antibakteri menggunakan tetrasiklin $1000 \mathrm{ppm}$ sebagai kontrol positif dan aquades untuk kontrol negatif. Uji pendahuluan aktivitas antibakteri ekstrak metanol daun mangga bacang digunakan konsentrasi 1000 ppm. Tetrasiklin banyak digunakan karena selain bersifat sebagai antibakteri, tetrasiklin memiliki spektrum luas yang artinya dapat menghambat pertumbuhan bakteri gram negatif dan gram positif (Mycek,2001).

Berdasarkan pengujian yang telah dilakukan menunjukkan adanya aktivitas antibakteri ekstrak metanol daun mangga bacang dengan terbentuknya zona bening di sekitar lubang sampel dengan diameter tertentu yang disebut dengan zona hambat. Zona hambat yang terbentuk diukur dengan menggunakan jangka sorong secara vertical, horizontal dan diagonal, kemudian dirata-rata dalam milimeter (Pratiwi, 2008). Uji aktivitas antibakteri konsentrasi 1000 ppm memiliki aktivitas sebesar 5,46 mm. Aktivitas antibakteri kontrol positif tetrasiklin1000 ppm menghasilkan diameter zona hambat 23,29 mm dan aquades sebagai kontrol negatif tidak menghasilkan aktivitas antibakteri yaitu $0 \mathrm{~mm}$.

Hasil penelitian menunjukan bahwa aktivitas antibakteri ekstrak metanol daun mangga bacang memiliki aktivitas sedang. Menurut Dewi (2010), aktivitas antibakteri ekstrak etanol buah mengkudu terhadap $E$. Aerogenes juga memiliki daya hambat sedang terhadap E. Aerogees. Kekuatan daya hambat bakteri dikatagorikan menurut Davis dan Stout (1971) dibagi menjadi tiga yaitu, sangat kuat (zona bening > $20 \mathrm{~mm}$ ), kuat (zona bening 10 $20 \mathrm{~mm}$ ), sedang (zona bening 5-10 mm), dan lemah (zona bening $<5 \mathrm{~mm}$ ) (Dewi, 2010).

Penentuan Konsentrasi Hambat Tumbuh Minimum Ekstrak Metanol Daun Mangga bacang
Penentuan konsentrasi hambat tumbuh minimum dilakukan untuk mengetahui konsentrasi hambat minimum ekstrak daun mangga bacang yang dibuat dengan cara pengenceran. Konsentrasi ekstrak metanol daun mangga bacang yang digunakan dalam penentuan KHTM yaitu 1000 ppm, 500 ppm, 250 ppm,125ppm,65ppm,30 ppm, $15 \mathrm{ppm}, 10 \mathrm{ppm}, 5 \mathrm{ppm}, 1 \mathrm{ppm}$. Kontrol positif yang digunakan pada penentuan KHTM digunakan tetrasiklin $\mathrm{HCl} 500 \mathrm{mg}$ (generik) dengan konsentrasi 1000 ppm sebagai antibiotik standar terhadap daya hambat ekstrak metanol daun mangga bacang pada E. aerogenes. Antibakteri dikatakan mempunyai aktifitas yang tinggi bila KHTM terjadi pada kadar sampel yang rendah namun mempunyai daya hambat besar terhadap bakteri uji (Wattimena, et.al., 1991).Hasil penentuan konsentrasi hambat minimum ekstrak metanol daun mangga bacang terhadap $E$. aerogenes dapat dilihat pada Gambar 1.

Berdasarkan hasil penelitian pada Gambar 1 menunjukan aktivitas antibakteri ekstrak metanol daun mangga bacang menurun dengan menurunnya konsentrasi. Konsentrasi ekstrak 1000 ppm sampai dengan 5 ppm menunjukkan aktivitas daya hambat dengan terbentuknya zona bening sedangkan pada konsentrasi 1 ppm sudah tidak dapat menghambat pertumbuhan bakteri $E$. Aerogenes. Konsentrasi paling rendah yang mampu menghambat pertumbuhan $E$. Aerogenes terdapat pada konsentrasi 5 ppm dengan zona hambat sebesar 1,78 mm. Berdasarkan analisis data menggunakan One Way ANOVA menunjukkan nilai yang signifikan, kemudian uji dilanjutkan menggunakan metode DUNCAN. Hal ini menunjukkan perbedaan yang nyata antara ekstrak metanol daun mangga bacang konsentrasi 5 ppm berbeda nyata dengan konsentrasi ekstrak lainnya. Konsentrasi 10 ppm tidak berbeda nyata dengan konsentrasi $15 \mathrm{ppm}$ dan $30 \mathrm{ppm}$, sehingga dapat dikatakan konsentrasi $10 \mathrm{ppm}, 15 \mathrm{ppm}$, dan $30 \mathrm{ppm}$ mempunyai pengaruh yang sama. Begitu 
pula konsentrasi 65 ppm tidak berbeda nyata dengan konsentrasi 125 ppm dan 250 ppm yang memiliki pengaruh sama. Konsentrasi 500 ppm, 1000 ppm dan kontrol positif menunjukan hasil yang berbeda nyata. Hal ini menunjukkan ekstrak metanol daun mangga bacang memiliki aktivitas antibakteri lebih rendah dari tetrasiklin namun dapat menghambat pertumbuhan bakteri E. Aerogenes hingga konsentrasi ekstrak 5 ppm. Berdasarkan hasil penelitian, tetrasiklin dengan konsentrasi 1000 ppm memberikan zona hambat terhadap E. aerogenes sebesar 23,29 mm. Menurut Gan dan Setia (1987), tetrasiklin merupakan antibiotik yang berspektrum luas. Mekanisme kerja tetrasiklin yaitu dengan menghambat sintesis protein pada ribosomnya.

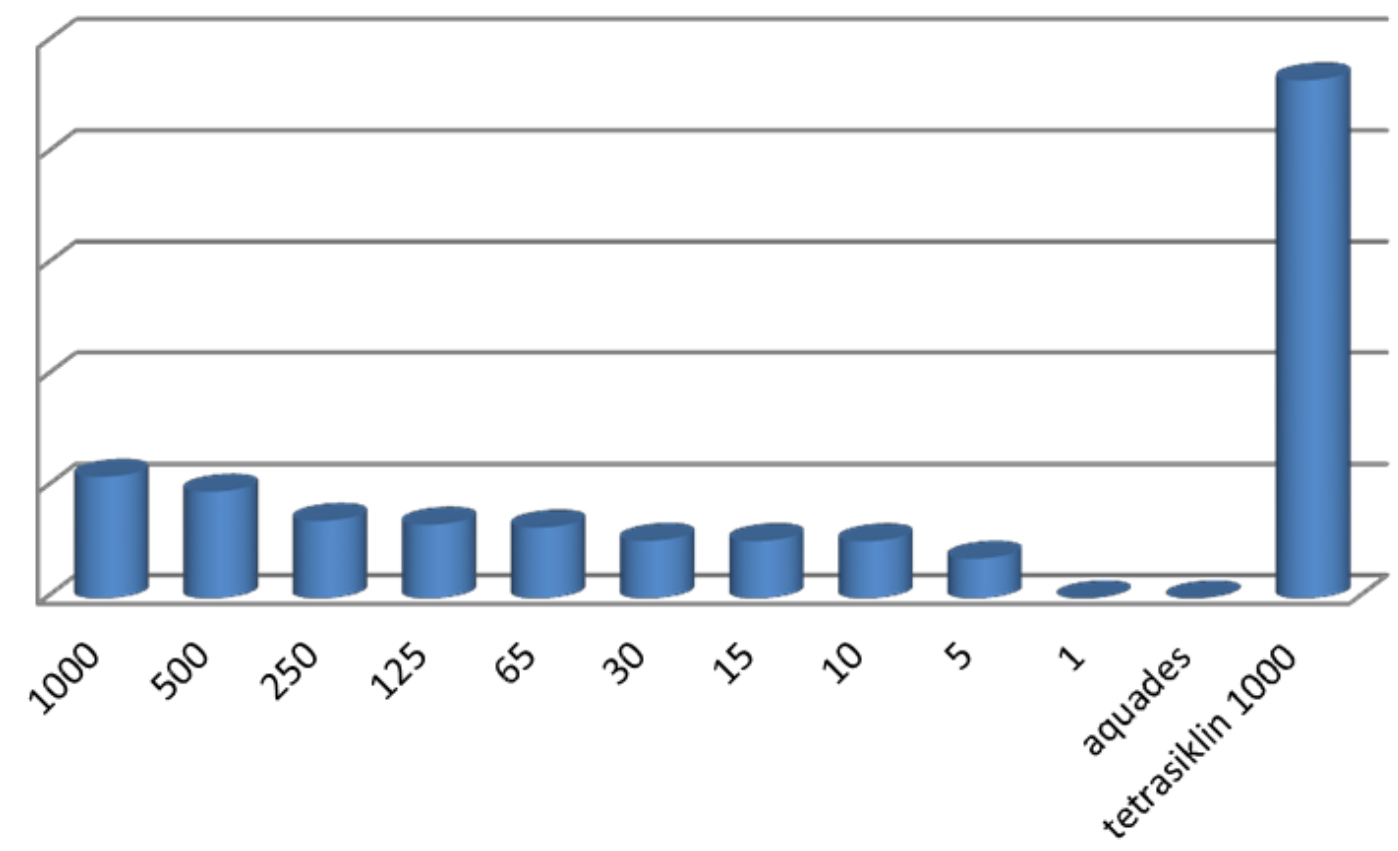

Gambar 1. Grafik Konsentrasi Hambat Tumbuh Minimum (KHTM) Ekstrak Metanol Daun Mangga Bacang terhadap E. aerogenes

\section{Identifikasi Senyawa Kimia Ekstrak Metanol Daun Mangga \\ Identifikasi senyawa metabolit} sekunder yang terkandung dalam daun mangga bacang dilakukan menggunakan metode uji fitokimia. Uji fitokimia digunakan untuk mengetahui adanya golongan senyawa metabolit sekunder seperti alkaloid, flavonoid, polifenol, terpenoid/steroid, saponin dan tanin. Hasil uji fitokimia ekstrak metanol daun mangga bacang dapat dilihat pada Tabel 1 .

Berdasarkan hasil uji fitokimia golongan senyawa metabolit sekunder yang terdapat dalam daun mangga bacang yaitu flavonoid, alkaloid, terpenoid, polifenol, tanin dan saponin. Uji fitokimia yang dilakukan menggunakan pelarut metanol yang bersifat polar, sehingga diharapkan dapat menarik senyawa metabolit yang bersifat polar seperti alkaloid, flavonoid, fenol, tanin, saponin dan steroid, sedangkan terpenoid bersifat nonpolar sehingga tidak dapat ditemukan pada skrining fitokimia (Markham,1998)

Uji fitokimia senyawa flavonoid menggunakan metode Wilstater. Menurut Sabir (2005), senyawa flavonoid dapat merusak permeabilitas dinding sel mikroba, berikatan dengan protein fungsional sel dan DNA sehingga mampu menghambat pertumbuhan mikroba. Flavonoid dapat menghambat komponen sel yang berfungsi mengeluarkan zat 
antimikroba. Komponen sel tersebut terdapat pada membran lipopolisakarida sel (Kuete, 2010).

Uji senyawa alkaloid dilakukan dengan menggunakan metode Mayer dimana penambahan $\mathrm{HCl}$ pada pereaksi Mayer berfungsi untuk membuat suasana menjadi asam karena golongan alkaloid bersifat basa. Hasil positif adanya alkaloid ditandai dengan terbentuknya endapan putih kekuningan. Alkaloid berperan sebagai antibakteri dengan cara berinteraksi dengan dinding sel bakteri yang berujung pada kerusakan dinding sel dapat berikatan dengan DNA bakteri yang menyebabkan kegagalan sintesis protein (Cowan, 1999).

Tabel 1. Hasil Identifikasi Senyawa Kimia Ekstrak Metanol Daun Mangga Bacang

\begin{tabular}{cll}
\hline Senyawa & Hasil & \multicolumn{1}{c}{ Keterangan } \\
\hline Flavonoid & positif & Terbentuk warna jingga \\
Alkaloid & positif & Terbentuk endapan putih \\
Steroid & positif & Larutan berwarna hijau \\
Terpenoid & negatif & Larutan berwarna hijau \\
Polifenol & positif & Larutan biru tua \\
Tanin & positif & Larutan berwarna biru tua \\
Saponin & positif & Busa yang stabil $\pm 1,5 \mathrm{~cm}$ \\
\hline
\end{tabular}

Alkaloid merupakan senyawa nitrogen yang memiliki kemampuan bioaktivitas dan memiliki aktivitas fisiologi yang tinggi dan telah digunakan secara luas dalam bidang pengobatan Pada uji alkaloid dengan pereaksi Mayer, diperkirakan nitrogen pada alkaloid akan bereaksi dengan ion logam $\mathrm{K}^{+}$dari kalium tetraiodomerkurat(II) membentuk kompleks kalium-alkaloid yang mengendap (Mustikasari, 2010).

Uji terpenoid dan steroid menggunakan pereaksi Libermann-Burchard yang merupakan campuran asam sulfat pekat dan asam asetat glasial. Hasil uji positif ditandai dengan terbentuknya warna merah jingga atau ungu untuk terpenoid dan hijau atau biru untuk steroid (Harborne, 1996). Hasil uji terpenoid dan steroid ekstrak metanol daun mangga bacang menunjukan hasil positif untuk steroid dengan terbentuknya warna hijau. Aktivitas antibakteri dari steroid melalui interaksi ion $\mathrm{Mg}^{2+}$ dan $\mathrm{Ca}^{2+}$ yang ada di membran sel yang mengakibatkan peningkatan permeabilitas membran luar pada bakteri gram negatif (Kayser,2005).

Uji polifenol dilakukan dengan menambahkan $\mathrm{FeCl}_{3} 5 \%$ pada ekstrak metanol daun mangga bacang, hasil positif polifenol ditandai dengan terbentuknya kompleks berwarna hijau, ungu, biru, atau hitam (Harborne, 1996). Fenol memiliki aktivitas antibakteri karena dapat mendenaturasi protein dan mengganggu fungsi membran sel sehingga menyebabkan sel menjadilisis.

Tanin memiliki aktivitas antibakteri yang berhubungan dengan kemampuannya untuk menginaktifkan adhesin sel mikroba juga menonaktifkan enzin, dan mengganggu transpot protein pada lapisan dalam sel (Cowan, 1999). Tanin menyerang polipeptida dinding sel sehingga pembentukan dinding sel menjadi kurang sempurna. Hal ini menyebabkan sel bakteri menjadi lisis karena tekanan osmotik maupun fisik sehingga sel bakteri akan mati. Struktur astrigen tanin berikatan dengan enzim dan substrat bakteri (Doughari, 2008). Tanin juga merupakan senyawa yang bersifat lipofilik sehingga mudah terikat pada dinding sel dan mengakibatkan kerusakan dinding sel (Sudira, et.al, 2011).

Uji saponin dilakukan menggunakan metode Forth, yaitu hidrolisis saponin dalam air. Timbulnya busa pada uji Forth 
menunjukkan adanya glikosida yang mempunyai kemampuan membentuk buih dalam air yang terhidrolisis menjadi glukosa dan senyawa lainnya (Marliana, 2005). Hasil positif ditunjukkan pada ekstrak metanol daun mangga bacang yang ditandai dengan terbentuknya busa yang stabil setinggi $1,5 \mathrm{~cm}$. Saponin bekerja dengan meningkatkan permeabilitas membran sel yang terjadi karena struktur bipolar yang dimiliki oleh saponin berinteraksi dengan komponen membran sel.

\section{Kesimpulan}

\section{DaftarPustaka}

Arifin, H., Anggraini, N., Handayani, D., \& Rasyid, R. (2006). Standarisasi Ekstrak Etanol Daun Eugeniacumini Merr. J. SainsTek. Far, Vol.11, No.2, Hal 88-93.

Brooks, G.F., J.S. Butel dan S.A. Morse. (2007). Mikrobiologi Kedokteran, Buku1. Penerjemah dan editor: Bagian Mikrobiologi Fakultas Kedokteran Universitas Airlangga, Edisi Pertama, Salemba Medika, Jakarta, hlm. 30-8, 317 -26.

Cowan (1999). Plant Product as Antimicrobial Agents, Clinical Microbiology Reviews, October, Vol. 12, No. 4, Hal. 564-582.

Davis \& Stout. (1971). Disc Plate Method of Microbiological Antibiotic Essay. Journal Of Microbiology. Vol 22 No 4.

Dewi, F. K. (2010). Aktivitas Antibakteri Ekstrak Etanol Buah Mengkudu (Morinda Citrifolia, Linnaeus) Terhadap Bakteri Pembusuk Daging Segar (Doctoral dissertation, Universitas Sebelas Maret Surakarta).

Doughari, J. And Manzara, S. (2008). In Vitro Antibacterial Activity of Crude Leaf Extracts of Mangifera indica Linn, African Journal of Microbiology Research., 2(1) 67-72.
Berdasarkan hasil penelitian ini diperoleh simpulan bahwa ekstrak metanol daun mangga bacang dapat menghambat pertumbuhan E. Aerogenes pada konsentrasi 1000 ppm dengan diameter zona hambat sebesar 5,46 mm. Ekstrak metanol daun mangga bacang memiliki Konsentrasi hambat tumbuh minimum (KHTM) terhadap E. Aerogenes yaitu pada konsentrasi $5 \mathrm{ppm}$ dengan diameter zona hambat 1,78 $\mathrm{mm}$. Golongan senyawa metabolit sekunder yang terdapat dalam ekstrak metanol daun mangga berdasarkan uji fitokimia yaitu senyawa flavonoid, alkaloid, stereoid, polifenol, tanin, dan saponin

Firdausi, I., Retnowati, R., \& Sutrisno, S. (2015). Fraksinasi Ekstrak Metanol Daun Mangga Kasturi(Mangifera casturi Kosterm) dengan Pelarut nbutanol. Jurnal Ilmu Kimia Universitas Brawijaya, Vol.1, No. 1, Hal.785.

Gandan Setia, B.(1987). Farmakologi dan Terapi Edisi IV. Fakultas Kedokteran. Depok:Universitas Indonesia.

Ganiswara, S.G. (2003). Farmakologi dan Terapi, Edisi 4. Jakarta: Fakultas Kedokteran Universitas Indonesia.

Harborne, J.B. (1987). Metode Fitokimia: Penuntun Cara Modern Menganalisis Tumbuhan Edisi Kedua. Bandung:ITB.

Harborne, J.B. (1996). Phytochemical Methods: A Guide to Modern Technique of Plant Analysis. London: Chapman \& Hall.

Irawati, H. (2011). Kontaminasi Awal dan Dekontaminasi Bakteri Patogen pada Jeroan Sapi dengan Iradiaso Gamma. Jurnal Penelitian. Jakarta: Pusat Aplikasi dan Radiasi, BATAN.

Kayser, F., Bienz, K., Eckert, J., Zinkernagel, R. (2005). Medical Microbiology. Thieme. New York. 
Kuete, V., Ngameni, B., Mbaveng, A. T., Ngadjui, B., Meyer, J. M., \& Lall, N. (2010). Evaluation of Flavonoids from Dorstenia Barteri for their Anti mycobacterial, Antigonorrheal and Anti-reverse Transcriptase Activities. Actatropica, 116(1), 100-104.

Markham, K.R. (1988). Cara Mengidentifikasi Flavonoida. Terjemahan Kosasih Padmawinata. Bandung:ITB

Marliana, S. D., \& Suryanti, V. (2005). Skrining Fitokimia dan Analisis Kromatografi Lapis Tipis Komponen Kimia Buah Labu Siam (Sechiumedule Jacq. Swartz.) dalam Ekstrak Etanol.B iofarmasi, 3(1), 2631.

Masibo, Mand He,Q. (2009). In Vitro Antimicrobial Activity and The Major Polyphenol in Leaf Extract of Mangifera indica L. Malaysian Journal of Microbiology. 5(2):73-80.

Mustikasari, K \& Ariyani, D. (2010). Skrining Fitokimia Ekstrak Metanol Biji Kalangkala (Litseaangulata). Sains dan Terapan Kimia. Vol. 4, No. 2, Hal. 131-136.

Mycek, Mary J. (2001). Farmakologi, ulasan bergambar Ed.2. Jakarta: Widya Medika.

Ningsih, D.R., Zusfahair, Purwati. (2014). Potensi Ekstrak Daun Kamboja (Plumeria Alba L.) Sebagai Antibakteri Dan Identifikasi Golongan Senyawa Bioaktifnya. Artikel Ilmiah. 2-4.

Pelczar, M.J. dan Chan, E.C.S. (1996). Dasar-dasar Mikrobiologi. Jilid 2. Penerjemah Ratna Sirihadioetomo. Jakarta:Universitas Indonesia Press.
Pratiwi, Suthanty Ika. (2008). Aktivitas Antibakteri Tepung Daun Jarak (Jatropha curcas L.) pada Berbagai Bakteri Saluran Pencernaan Ayam Broiler Secara in vitro.Skripsi. Bogor:Fakultas Peternakan Institut Pertanian Bogor.

Purwaningsih, E., Hanani, E., Arnalia, P., Krisnamurti, D. (2013). Efek Kelasi Ekstrak Air Mangifera foetida pada Serum Penderita Talesemi. $J$. IndonMed Assoc. 61(8);321-325.

Sabir, A. (2005). Aktivitas Antibakteri Flavonoid Propolis Trigona sp. Terhadap Bakteri Streptococcus mutans (in vitro). Jurnal Kedokteran Gigi. Vol.38, No.3, Hal. 135-141.

Sudira, IW, Merdana, IM \& Wibawa, IP (2011).Uji Daya Hambat Ekstrak Daun Kedondong (Lannea grandis Engl) terhadap Pertumbuhan Bakteri Erwinia Carotovora, Buletin Veteriner Udayana, Vol. 3, No. 1, Hal. 45-50.

UNAIDS. (2007). AIDS Epidemic Update: Global Summary of The AIDS Epidemic. Geneva: WHO Library Cataloguing Data

Voigt, R. (1995). Buku Pelajaran Teknologi Farmasi. Diterjemahkan oleh Soendani N. S. Yogyakarta:UGM Press.

Volk dan Wheeler. (1990). Mikrobiologi Dasar Edisi Kelima Jilid I. Jakarta: Erlangga

Wattimena, J. R. (1991). Farmakodinamik dan Terapi Antibiotik. Yogyakarta: UGM Press. 